\title{
Assessing EFL Teachers' Perception and Their Implementation of Writing Tasks: The Case of Mekane-Eyesus, Mikrie and Koma Secondary Schools
}

\author{
Asafew kelebu Abtew \\ Mekdela Amba University College of Social Science and Humanities Department of English language and \\ literature, Ethiopia
}

\begin{abstract}
This qualitative study endeavored to assess teachers' perception and their implementation of writing tasks. The participants of the study were grade 10 EFL teachers at Mekane Eyesus, Koma and Mikrie secondary schools, Estie woreda. A questionnaire and interview were made to gather data on teachers' perception and their implementation of writing tasks. Besides, observation was held to see teachers' implementation of writing tasks. The data was analyzed qualitatively. The questionnaire and interview results showed that the teachers have good perception on writing tasks. However, the data in observation and questionnaire revealed that teachers didn't implement writing tasks properly. Finally, it was concluded that teachers didn't implement writing tasks as they perceive it and they didn't teach students following the stages of writing. On the basis of the findings and the conclusions made, it is recommended that teachers should teach the writing tasks in stages of writing and they should support the students in each stages of writing.
\end{abstract}

Key terms: task, perception, stages of writing, writing tasks

DOI: $10.7176 /$ JLLL/79-04

Publication date:May $31^{\text {st }} 2021$

\section{Introduction}

Long before, writing was not given emphasis. Regarding to this, White (1989) points out that second language teaching of writing was highly influenced by the audio lingual approach until the end of 1950s. At that time, writing was considered as less important when compared with other language skills. He added that the focus of teaching writing was not on helping students to communicate using the skill rather to make the students accurate in grammar and vocabulary. This way of teaching affected the students' writing skill development for years.

Nowadays, classroom methodology uses communicative approach. Communicative approach of teaching emphasis on task-oriented activities that involve, where possible exchange of information and free use of language without undue concern for mistakes (Littlewood, 1981; Nunan, 1988). A task is currently considered to be the most effective means of promoting second language acquisition in the class room. According to Richards and Rodgers (2004:223), "engaging learners in task work provides a better context for the activation of learning process."

Communicative tasks are very important for developing learners' second language and foreign language writing skill. In relation to this, Richards and Rodgers (2004) and Nunan (1989), state that communicative tasks provide a purpose and a desire to communicate. They also added that tasks allow students to practice using all of the language they know in situations that resemble real settings. In such activities, students are encouraged to work together to develop a plan, resolve a problem, or complete a task. According to Richards and Rogers (2001:228) "Tasks are believed to foster a process of negotiation, modification, rephrasing and experimentation that are at the heart of second language learning." Therefore, tasks (activities) have a vital role especially in the more recent version of communicative language teaching (CLT), which is Task-Based Language Teaching (TBLT).

In the context of our country, Ethiopia, some researches disclosed that the teaching of writing tasks was ineffective and the writing performance of students of high school and preparatory schools are very low (Geremew, 1999; Alamirew, 2005; Desalegn, 2011). In line with this Hailemariam (2012) adds that it is a common phenomenon that the level of Ethiopian students' language skill in general is very low after they have learnt the English language from grade one to preparatory school level. Particularly, their writing skill is often found to be below the expectations.

In the context of our country, some research studies show that the teaching of writing was ineffective and the writing performance of students of high school and higher institutions are low (Abiy, 2013; Dawit, 2013; Hailemariam , 2012; Desalegn, 2011). Abiy's study is different from this study in many ways. Thematically Abiy's study was on high school students' writing skills and their English language proficiency as predictors of their English language writing performance. He didn't see the teachers' perception on writing tasks, implementation of writing task, and the correspondence of teachers' perception and their implementation of writing tasks. His study was not on Estie district high schools. 
Dawit studied on enhancing students' writing skills through the genre approach at Bahir Dar University and his study was at university students, but not at high school.

Furthermore, Hailemariam's study was on difficulty level of the writing tasks and the cause of students' writing problems. Moreover, Dessalegn's study focused on the implementation of the different approaches to teaching of English.

Therefore, in the researcher's understanding there was a gap which has not been touched yet. As a result, this study was designed to fill this gap by exploring EFL teachers' perception and their practice of teaching writing tasks at Mikrie, Koma and Mekane Eyesus Secondary Schools.

The general objective of the study was to explore EFL teachers' perception and their implementation of writing tasks. Whereas, the specific objectives of the study were to:

1. explore secondary school EFL teachers' perception on writing tasks.

2. explore secondary school EFL teachers' implementation of writing tasks.

3. investigate if EFL teachers' teach writing tasks as they perceive writing tasks.

\section{RESEARCH METHODOLOGY}

\subsection{Research Design}

The study aimed at exploring EFL teachers' perception on writing tasks and their practice of teaching writing task at Mekane Eyesus, Mikrie and Koma Secondary and preparatory schools. The research frame work used in this study was mixed research design i.e. the combination of both quantitative and qualitative methods. The main supposition behind using this method was that it provides better understanding of the research problem and answers the research questions than any other approach (Cresswel 2014). In relation to this, Ary et al (2010: 567) states that mixed methods research can take advantage of the combined strengths of qualitative and quantitative approaches and can use the strengths of one method to overcome the weaknesses of another. It could provide stronger evidence for a conclusion through validation of findings. Therefore, if mixed method gives a better understanding of the research problem and is better than a single method design, then it is worth considering for the purpose of exploring teachers' perception and implementation of writing tasks.

\subsection{Participants of the Study}

All grade 10 English teachers at Koma, Mikrie and Mekane Eyesus secondary and preparatory schools were identified as the population of the study. The total number of grade 10 English teachers was 30 that was 14 EFL teachers in Mekane Eyesus, 8 EFL teachers in Mikrie and 8 EFL teachers in Koma secondary schools. These schools were selected in view of the fact that the researcher had a very good acquaintance with some of the English teachers working there as a result of which the researcher was encouraged to have a free and frequent communication with them while administering the tools. The researchers' being familiar to them also helped him a lot in getting real and sufficient information for the study. In addition, proximity of the schools from the researcher's living place and study center had some role during the selection of the schools. When the research site is convenient and manageable size for the researcher, it has its own effect in determining the quality of the final findings (Kumar 2006).

\subsection{Samples and sampling technique}

The researcher used comprehensive sampling technique to select teachers for questionnaire. This was because the samples were manageable. Moreover, the researcher believed that these samples were enough to collect valid and reliable information. However, interviewing and observing the whole 30 teachers was tiring and unmanageable. Therefore, the researcher selected some teachers as a sample for interview and observation. As a result, the researcher selected 5 teachers for this purpose using the lottery method. As a result, 3 teachers from Mekane Eyesus, one teacher in Mikrie and one teacher in Koma secondary schools were selected for interview and observation.

\subsection{Data gathering tools}

2.4.1. Observation

It is used to collect data on teachers' practice of teaching the writing tasks. More specifically, the researcher observed how the teachers passed the different stages of writing suggested by Pincas (1989), Byrne (1991) and White (1989). Therefore, 15 periods of classroom observations were conducted. That is each sample teacher was observed 3 times. All the observations were conducted during the writing period. During the observation, the researcher took note on the teaching learning process. The researcher himself conducted the observation. In all the observations made, the researcher tried his best to make his presence not disturb the class. The researcher used video recorder during observation.

\subsubsection{Questionnaire}

It was used to explore teachers' teaching of the writing tasks and their perceptions on the writing tasks. The 
researcher adapted some of the research questions from Teshome Tola and some of the questions were prepared from the review of review of related literature. The researcher prepared and distributed 32 close ended questions. The researcher used likert scale to gather data through questionnaires. The likert scale allows individuals to respond to different statements between the extremes on the continuum that represent their attitude that is providing responses to scales from strongly agree to strongly disagree to each statement. These offer the respondents a reasonable range of answers to choose from as it is composed of a variety of answers: strongly agree, agree undecided, disagree and strongly disagree.

In general teachers' questionnaire had the following sections.

1. Personal Information section-used to get an accurate self-description of the respondents,

2. Perception of teachers' on writing tasks.

3. Teachers implementation of the different stage of writing while they teach writing tasks The return rate of the questionnaires was $100 \%$.

\subsubsection{Interview}

It was designed to get further information, which could validate the response revealed through the questionnaire and classroom observation. Concerning to this, Selinger and Sahomy (1989) state that interview is believed to substantiate the information obtained from the questionnaires and classroom observations. Interview was used to collect data from grade 10 English teachers (5 in number): to obtain attitude of teachers on teaching writing task and to gather data on how teachers implement writing tasks in class. The interview questions were 7 in number and they were semi structured because the researcher will come up with additional questions during the interview.

\subsection{Data collection procedure}

The researcher employed the following data collection procedures. First, the researcher made contact with the principals of the schools to get permission to carry out the study and explained the purpose of the study. Second, the researcher explained the purpose of the research to the selected samples to bring awareness and make confidence on them.

Before the researcher conducted the observation, he made contact with classroom teachers and got permission for observation. Then, they decided the dates and periods of writing lesson of the observation. Next, the researcher conducted the observation by sitting at the back and wrote the teaching learning process. Each sample teacher was observed in three different writing periods in one of their sections.

In questionnaire, the researcher explained the objective of the questionnaire for the sample teachers. After he created awareness, he distributed the questionnaire for the samples and reminded them to fill it independently. Finally he collected the distributed questionnaires.

During interview which was semi structured, the researcher first prepared the interview questions for teachers. Next, he asked willingness from samples to be interviewed and determined the time for interview with the samples. After that he conducted the interview. During interview, the researcher recorded the responses by his mobile. Then, he transcribed the recorded data in to paper.

In general, the procedure of data gathering tools started with administration of the classroom observations followed by questionnaires and then interview. The reason why the researcher made the observation first was that teachers may show artificial behavior (may change the way of teaching) if questionnaires and interview given before. Generally, more than two months of time was utilized from the inception up to the completion of the data collection process.

The researcher used both quantitative and qualitative methods of data analysis. First, the observation data was analyzed using qualitative data analysis technique. Second, data from teachers' questionnaire followed by students' questionnaire were tallied and analyzed quantitatively using percentage. At last, the interview data were analyzed qualitatively using words, phrases and sentences.

\section{DATA ANALYSIS}

This chapter presents the analyses of both the qualitative and quantitative data collected about teachers' perceptions and their teaching of writing tasks. Therefore, findings of class room observation, teachers' questionnaire and teachers' interview were analyzed respectively.

\subsection{Analysis of Classroom Observation Data}

The main purpose of the observation was to answer how grade 12 English teachers teach the writing tasks. Thus, the investigator observed five grade 12 English teachers while teaching writing tasks. The researcher focused on whether the teachers were following the three writing task phases or not. More specifically in his observation, the researcher focused on what the teachers did in the different stages of writing process. The observation data were analyzed in the following ways. 


\section{Pre task phase}

Before, the students start writing their paragraph/essay, they have to do different pre writing activities. During prewriting, the teachers have to do a lot to help students do pre task activities. For example, teachers should initiate learners to discuss in group or in pair, to prepare mind map, charts, and tables which help the students to brainstorm about the topic. In addition, teachers should help the students to organize their idea based on the brainstorming in the planning stage and to prepare an outline. However, none of the sample teachers did these prewriting tasks.

As the researcher's observation what the teachers in the selected schools did in the pre task phase was giving preliminary introduction about the topic like todays lesson is writing. You will write a descriptive paragraph/narrative paragraph etc. Then, they ordered the students to take out their exercise book and to write.

From the observation of the teaching and learning process in the pre task phase, we can comprehend that the teachers give oral introduction. However, they didn't give time for students to discuss in group/pair, to prepare mind map and outline and to organize their idea in the pre task phase. This implies that the teachers gave little attention to the pre-task activities (the brainstorming and planning stage of writing).

\section{While tasks phase}

After students do the pre writing tasks, they start doing the while writing tasks. While writing tasks are done based on the discussions/concepts of the pre task phase. In the while writing stage, the students start writing their first draft. In this phase the teachers should help students by moving through the desks and monitor students to focus on their task.

As the researcher observed the actual teaching of writing tasks, the students started doing the writing tasks in this phase that means they didn't have any concept /idea they got from the pre writing tasks. This was because the teachers didn't implement the pre task phase properly. After they heard the oral introduction given by the teacher they started writing in this phase. This means that their writing was without mind map, outline and without planning. In this writing phase, as the researcher observed, most of the teachers gave little help for the students. The teachers simply ordered the students to write and they sat somewhere and tried to keep the discipline of the class. Most of the time they didn't go round and monitor the student's progress and they didn't give any support for the students. In addition, most of the teachers didn't monitor whether the students were doing the writing tasks or doing any other thing out of the topic. As the researcher observed, many of the students were not observed genuinely interacting in the writing task. Some of the students were talking about other issues which were not academicals in L1 (Amharic), while others were simply sat alone without doing anything.

In some of the observations, some teachers skipped the writing tasks by giving it as homework after they gave oral introduction. In the next period, those teachers started the day's lesson by moving round and randomly looking two or three students' exercise book.

Based on the analysis of the observation in the while task phase, most teachers gave writing tasks for the students but they didn't control and support them. What the teachers did in this phase was delivering the writing tasks for the students and keeping the discipline of the class while some others were observed skipping the writing tasks.

From the above analysis, it is possible to say that most of the teachers didn't implement the while writing activities in a way which help students to do the writing tasks in a communicative way. In this phase, majority of the teachers were not playing their roles effectively. What the teachers did in this phase didn't match with the fact what the teachers should do in the while task phase that Willis (1996) mentioned. He stated that in the while writing stage, teachers are required to encouraging all students to take part, making sure that the students are doing the right task and are clear about the objectives, assist students in their difficulties and go round the class and monitor the process.

\section{Post task phase}

The students should make self-correction, peer correction and teacher correction after they do their first draft. After that the students should rewrite their first draft by incorporating the comments. In this phase teachers should give time for students for discussions that are for self and peer correction.

However, what the researcher observed was that, after the students finished their first draft, the teachers didn't give time for peer and self-correction. Besides, the teachers didn't check student's progress and didn't give written comment on students' exercise book. What the teachers did was selecting one or two students to read his work and giving general comment for the whole students. Most of the teachers also did nothing in most of the observations in post task phase. These teachers were observed ordering the students to finish some part of the while task phase and the post task phase in their home. The majority of the students were not seen rewriting their first draft based on comments. Once they finished their first draft, they didn't do further that.

Generally, in this phase, the teachers gave general comment for their students. However, they didn't make 
students to peer/self-correction. In addition to this, they didn't make students to rewrite the first draft. This implies that this phase was given very little attention by teachers. The teachers didn't play their role effectively.

In general, from the analysis of observation data it is possible to say that most of the teachers didn't implement the writing tasks in phases. Especially they didn't implement the brainstorming, the planning, the revising, and the editing and rewriting stages of writing. We can also say that the majority of the teachers didn't play their role effectively in each stage of writing. This result confirms with Hedge, (2005) and Squire, (1979). They stated that instead of engaging students in regular classroom and extensive practices of writing through the process approach; generating ideas, drafting their paragraph and checking their writing individuals or in groups teachers, expect learners to produce a piece of written product for evaluation and this has a negative effect on students writing skill.

\subsection{Analysis of Data from Teachers' Questionnaire}

This questionnaire was mainly used to gather data on teachers' perception about writing task and their practice of teaching writing tasks. Therefore, the analysis of teachers' questionnaire is presented below under these two thematic areas.

3.2.1 Analysis of teachers' questionnaire about their perception of writing tasks.

Table 1: Teachers' response about their perception of nature of writing tasks.

\begin{tabular}{|c|c|c|c|c|c|c|c|c|c|c|c|c|c|}
\hline \multirow[b]{2}{*}{$\mathrm{z}^{\prime}$} & \multirow[t]{2}{*}{ Items } & \multicolumn{2}{|l|}{$\mathrm{Sa}$} & \multicolumn{2}{|l|}{ A } & \multicolumn{2}{|l|}{ Un } & \multicolumn{2}{|l|}{$\mathrm{D}$} & \multicolumn{2}{|l|}{ SD } & \multicolumn{2}{|c|}{ Total } \\
\hline & & $\begin{array}{l}\bar{d} \\
\stackrel{\Xi}{\Xi} \\
\text { Zे }\end{array}$ & 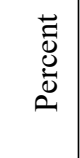 & $\begin{array}{l}\bar{\Xi} \\
\text { ఏ } \\
\text { 乙 }\end{array}$ & 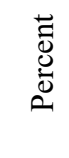 & $\begin{array}{l}\dot{\bar{\Xi}} \\
\text { 㭉 } \\
\text { Z }\end{array}$ & 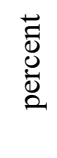 & $\begin{array}{l}\dot{\bar{\Xi}} \\
\text { छ } \\
\text { Z }\end{array}$ & 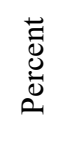 & $\begin{array}{l}\dot{\bar{\Xi}} \\
\stackrel{\Xi}{\Xi} \\
\bar{Z}\end{array}$ & 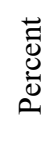 & $\begin{array}{l}\dot{\Phi} \\
\stackrel{\Xi}{\Xi} \\
\text { Z }\end{array}$ & 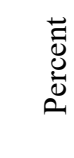 \\
\hline 1 & $\begin{array}{l}\text { Writing tasks require regular } \\
\text { practice }\end{array}$ & 20 & 66.7 & 10 & 33.3 & - & - & - & - & - & - & 30 & 100 \\
\hline 2 & $\begin{array}{l}\text { Writing tasks require critical } \\
\text { thinking }\end{array}$ & 28 & 93.3 & 2 & 6.7 & - & - & - & - & - & - & 30 & 100 \\
\hline 3 & $\begin{array}{l}\text { Writing tasks are not as } \\
\text { important as grammar and } \\
\text { vocabulary for students. }\end{array}$ & - & - & - & - & 3 & 10 & 12 & 40 & 15 & 50 & 30 & 100 \\
\hline
\end{tabular}

Key: $\mathrm{SA}=$ Strongly agree, $\mathrm{A}=$ Agree, $\mathrm{Un}=$ Undecided, $\mathrm{D}=$ Disagree, $\mathrm{SD}=$ Strongly disagree

As it is shown in table one of item $1,66.7 \%$ and $33.3 \%$ of the teachers strongly agree and agree respectively that writing tasks require regular practice. In addition to this, $93.3 \%$ of the teachers strongly agree that writing tasks require critical thinking. Moreover, $40 \%$ and $50 \%$ of the teachers disagree and strongly disagree respectively with the statement writing tasks are not as important as grammar and vocabulary for students. This indicates that they believed that writing tasks are as important as grammar and vocabulary.

From the above analysis we can summarize the data in table one that teachers believe that writing tasks needs regular practice and critical thinking and they are as important as grammar and vocabulary. The result implies that the teachers have positive perception about the nature of writing tasks. 
Table 2: Teachers' response about their perception of teaching writing tasks.

\begin{tabular}{|c|c|c|c|c|c|c|c|c|c|c|c|c|c|}
\hline \multirow[b]{2}{*}{$\mathrm{Z}^{\prime}$} & \multirow[t]{2}{*}{ Items } & \multicolumn{2}{|l|}{$\mathrm{Sa}$} & \multicolumn{2}{|l|}{ A } & \multicolumn{2}{|l|}{ Un } & \multicolumn{2}{|l|}{$\mathrm{D}$} & \multicolumn{2}{|l|}{ SD } & \multicolumn{2}{|c|}{ Total } \\
\hline & & $\begin{array}{l}\dot{\bar{\Xi}} \\
\grave{\Xi} \\
\text { Z }\end{array}$ & 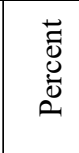 & $\begin{array}{l}\overline{\bar{\delta}} \\
\bar{\Xi} \\
\bar{Z}\end{array}$ & 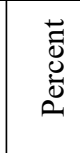 & $\begin{array}{l}\bar{\Xi} \\
\stackrel{\Xi}{\Xi} \\
\text { Z }\end{array}$ & 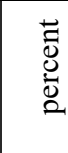 & 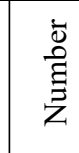 & 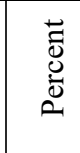 & $\frac{\bar{D}}{\bar{E}}$ & 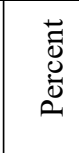 & $\begin{array}{l}\bar{\Xi} \\
\stackrel{\Xi}{\Xi} \\
\bar{z}\end{array}$ & 苞 \\
\hline 4 & $\begin{array}{l}\text { At high school level, it is not } \\
\text { necessary to teach writing tasks } \\
\text { because students can learn it at higher } \\
\text { institutions. }\end{array}$ & - & - & - & - & - & - & 11 & 36.7 & 19 & 63.3 & 30 & 100 \\
\hline 5 & $\begin{array}{l}\text { Teaching writing tasks of the text } \\
\text { book is helpful to improve students' } \\
\text { writing skill. }\end{array}$ & 16 & 53.3 & 13 & 43.3 & 1 & 3.3 & - & - & - & - & 30 & 100 \\
\hline 6 & $\begin{array}{l}\text { Teaching writing tasks is more } \\
\text { difficult than teaching other tasks } \\
\text { (listening task, speaking task and } \\
\text { reading task }\end{array}$ & 11 & 36.7 & 13 & 43.3 & 4 & 13.3 & 2 & 6.7 & - & - & 30 & 100 \\
\hline 7 & $\begin{array}{l}\text { Teaching writing tasks in English } \\
\text { requires more effort than teaching } \\
\text { grammar, vocabulary and other } \\
\text { language skills }\end{array}$ & 21 & 70 & 6 & 20 & - & - & 3 & 10 & - & - & 30 & 100 \\
\hline 8 & $\begin{array}{l}\text { In the process of teaching writing at } \\
\text { high school level, more focus should } \\
\text { be given to grammar and vocabulary. }\end{array}$ & 1 & 3.3 & 5 & 16.7 & - & - & 20 & 66.7 & 4 & 13.3 & 30 & 100 \\
\hline 9 & $\begin{array}{l}\text { Teaching writing tasks using product } \\
\text { approach of teaching is better than the } \\
\text { process approach of teaching to } \\
\text { improve students writing skill. }\end{array}$ & - & - & 4 & 13.3 & - & - & 24 & 80 & 2 & 6.7 & 30 & 100 \\
\hline 10 & $\begin{array}{l}\text { In the process of teaching writing, } \\
\text { making students brainstorm for ideas, } \\
\text { write outlines, write a first draft, } \\
\text { revise and edit it is a waste of time. } \\
\text { Therefore, it is not necessary. }\end{array}$ & - & - & - & - & - & - & 20 & 66.7 & 10 & 33.3 & 30 & 100 \\
\hline
\end{tabular}

Key: $\mathrm{SA}=$ Strongly agree, $\mathrm{A}=$ Agree, $\mathrm{Un}=$ Undecided, $\mathrm{D}=$ Disagree, $\mathrm{SD}=$ Strongly disagree

As it is indicated in table 2 of item $4,11(36.7 \%)$ and $19(63.3 \%)$ of the teachers disagree and strongly disagree respectively with the idea of item 4 . These teachers perceive that students should learn writing tasks and writing tasks should not be left to higher institutions. In item five of the same table, 53.3\% and $43.3 \%$ of the teachers strongly agree and agree respectively that teaching writing tasks of the text book is helpful to improve students' writing skill. In item 6 too, the majority of the teachers $(80 \%)$ perceive that teaching writing tasks is more difficult than teaching other tasks (listening task, speaking task and reading task). In item 7, 70\% and 20\% of the teachers strongly agree and agree respectively that teaching writing tasks in English requires more effort than teaching grammar, vocabulary and other language skills. From responses of item 6 and 7 , we can imply that writing tasks are challenging for teachers in terms of knowledge and effort.

In item 8 of table two, $80 \%$ of the teachers perceive that in the process of teaching writing at high school level, more focus should not be given to grammar and vocabulary. In item $9,80 \%$ of the teachers disagree with the idea teaching writing tasks using product approach of teaching is better than the process approach of teaching to improve students writing skill. This implies that the teachers perceive that they should teach writing tasks by involving students in the process of writing to improve their writing skill. Similarly, in item $10,66.7 \%$ and $33.3 \%$ of the respondents disagree and strongly disagree respectively with the idea in the process of teaching writing, making students brainstorm for ideas, write outlines, write a first draft, revise and edit it is a waste of time.

Generally, we can summarize the idea in table two that the teachers believed that making students to practice the writing tasks is helpful for students' writing skill improvement. We can also understand from the table that the teachers perceive that writing tasks should be taught in high school using process approach of teaching writing. Moreover, teachers believe that teaching writing tasks require high demand from teachers. Therefore, we can conclude that the teachers have good perception on teaching writing tasks. 
Table 3: Teachers' response about their perception on feedback.

\begin{tabular}{|c|c|c|c|c|c|c|c|c|c|c|c|c|c|}
\hline \multirow[b]{2}{*}{ 이 } & \multirow[b]{2}{*}{ Items } & \multicolumn{2}{|l|}{$\mathrm{Sa}$} & \multicolumn{2}{|l|}{ A } & \multicolumn{2}{|l|}{ Un } & \multicolumn{2}{|l|}{ D } & \multicolumn{2}{|l|}{ SD } & \multicolumn{2}{|c|}{ Total } \\
\hline & & $\begin{array}{l}\overline{\grave{D}} \\
\stackrel{\Xi}{\Xi} \\
\bar{z}\end{array}$ & 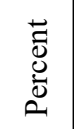 & $\begin{array}{l}\dot{\bar{\Xi}} \\
\text { छ } \\
\text { Z }\end{array}$ & $\begin{array}{l}\overrightarrow{0} \\
\stackrel{0}{0} \\
\stackrel{0}{0}\end{array}$ & $\begin{array}{l}\dot{\bar{\Xi}} \\
\text { छे } \\
\text { Zे }\end{array}$ & 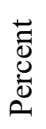 & $\begin{array}{l}\dot{\bar{\Xi}} \\
\text { छ } \\
\text { Zे }\end{array}$ & $\begin{array}{l}\stackrel{\overrightarrow{0}}{0} \\
\stackrel{0}{0} \\
\stackrel{0}{2}\end{array}$ & $\begin{array}{l}\dot{\Phi} \\
\stackrel{\Xi}{\Xi} \\
z\end{array}$ & 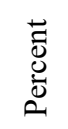 & $\begin{array}{l}\grave{\bar{D}} \\
\text { छ } \\
\bar{\Xi}\end{array}$ & 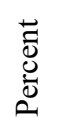 \\
\hline 11 & $\begin{array}{l}\text { Making students correct each other's } \\
\text { written work is helpful for developing } \\
\text { students' writing skills }\end{array}$ & 25 & 83.3 & 5 & 16.7 & - & - & - & - & - & - & 30 & 100 \\
\hline 12 & $\begin{array}{l}\text { Teachers' written feedback can help } \\
\text { learners improve their writing skills. }\end{array}$ & 21 & 70 & 9 & 30 & - & - & - & - & - & - & 30 & 100 \\
\hline 13 & $\begin{array}{l}\text { Giving feedback on students' written } \\
\text { product is difficult task, so teachers } \\
\text { should not waste their time on giving } \\
\text { feedback. }\end{array}$ & - & - & 4 & 13.3 & - & - & 18 & 60 & 8 & 26.7 & 30 & 100 \\
\hline 14 & $\begin{array}{l}\text { Making students rewrite what they } \\
\text { have written based on the feedback } \\
\text { helps them to write better. }\end{array}$ & 29 & 96.7 & 1 & 3.3 & - & - & - & - & - & - & 30 & 100 \\
\hline
\end{tabular}

Key: $\mathrm{SA}=$ Strongly agree, $\mathrm{A}=$ Agree, $\mathrm{Un}=$ Undecided, $\mathrm{D}=$ Disagree, $\mathrm{SD}=$ Strongly disagree

As it is shown in the table 3,83.3\% of the teachers perceive that peer correction helps students to develop their writing skill. In addition to this in item $12,70 \%$ and $30 \%$ of the teachers strongly agree and agree respectively that teachers' feedback is important to develop students' writing skill. In item 13 of table 3,60\% and $26.7 \%$ of the teachers disagree and strongly disagree with the idea giving feedback on students' written product is difficult task, so teachers should not waste their time on giving feedback. Almost all (96.7\%) of the respondents answered that making students rewrite what they have written based on the feedback helps them to write better.

From the data in table 3 we can summarize that the teachers perceive that peer feedback and teachers' feedback is helpful to improve students writing skill. The teachers also perceive that rewriting is helpful to improve one's writing skill. This result implies that the teachers have positive perception on feedback.

3.2.2. Analysis of data from Teacher's questionnaire about their teaching of writing tasks.

This section of questionnaire was aimed to explore how the teachers pass through different stages of writing process when they teach writing tasks. This is because now a days, there is a relative consensus among writing scholars that writing by its nature is a process in which a number of operations go simultaneously (Hedge, 2005; McDonough and Shaw, 1993; White and Arndt, 1991). Therefore, the investigator wants to investigate how the teachers go through the different stages of writing that are mentioned by the above researchers.

Table 4: Teachers 'response about their practice of teaching writing task in brainstorming stage.

\begin{tabular}{|c|c|c|c|c|c|c|c|c|c|c|c|c|c|}
\hline \multirow[b]{2}{*}{$z^{\prime}$} & \multirow[b]{2}{*}{ Items } & \multicolumn{2}{|l|}{$\mathrm{Sa}$} & \multicolumn{2}{|l|}{ A } & \multicolumn{2}{|l|}{ Un } & \multicolumn{2}{|l|}{ D } & \multicolumn{2}{|c|}{ SD } & \multicolumn{2}{|c|}{ Total } \\
\hline & & $\begin{array}{l}\dot{\bar{D}} \\
\stackrel{\Xi}{\Xi} \\
\text { Z }\end{array}$ & 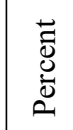 & 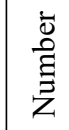 & $\begin{array}{l}\stackrel{\overrightarrow{0}}{0} \\
\stackrel{0}{0} \\
0\end{array}$ & $\begin{array}{l}\grave{\bar{D}} \\
\grave{\Xi} \\
\bar{\Xi}\end{array}$ & 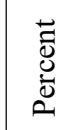 & $\begin{array}{l}\dot{\bar{\Xi}} \\
\stackrel{\Xi}{\Xi} \\
\text { Z }\end{array}$ & $\begin{array}{l}\overrightarrow{0} \\
\stackrel{0}{0} \\
\stackrel{0}{0} \\
2\end{array}$ & $\begin{array}{l}\dot{\Phi} \\
\stackrel{\Xi}{\Xi} \\
\text { Z }\end{array}$ & $\begin{array}{l}\stackrel{.}{0} \\
\stackrel{0}{0} \\
\stackrel{0}{0}\end{array}$ & $\begin{array}{l}\dot{\bar{\Xi}} \\
\stackrel{\Xi}{\Xi} \\
\text { Z }\end{array}$ & 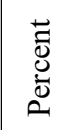 \\
\hline 15 & $\begin{array}{l}\text { I give oral introduction and explain } \\
\text { meanings of key terms which help } \\
\text { students do the task. }\end{array}$ & 17 & 23.3 & 12 & 40 & 1 & 3.3 & - & - & - & - & 30 & 100 \\
\hline 16 & $\begin{array}{l}\text { I order my students to discuss in pair } \\
\text { and in group about the writing task in } \\
\text { the brainstorming stage }\end{array}$ & - & - & 6 & 20 & 2 & 6.7 & 5 & 16.7 & 17 & 56.7 & 30 & 100 \\
\hline 17 & $\begin{array}{l}\text { Before I order the students to do the } \\
\text { writing task, I order the students to } \\
\text { prepare charts, tables and think about } \\
\text { points that should be included and to } \\
\text { write them as they come to their mind. }\end{array}$ & 4 & 13.3 & 7 & 23.3 & - & - & 17 & 56.7 & 2 & 6.7 & 30 & 100 \\
\hline 18 & $\begin{array}{l}\text { Before I order the students to do the } \\
\text { writing task, I ordered the students to } \\
\text { prepare a mind map about their } \\
\text { writing task }\end{array}$ & & & 10 & 33.3 & 1 & 3.3 & 10 & 33.3 & 9 & 30 & 30 & 100 \\
\hline
\end{tabular}

Key: $\mathrm{SA}=$ Strongly agree, $\mathrm{A}=$ Agree, $\mathrm{Un}=$ Undecided, $\mathrm{D}=$ Disagree, $\mathrm{SD}=$ Strongly disagree 
This table is about teachers' practice of the brainstorming stage of process writing. As it is shown in table 4 of item $15,23.3 \%$ and $40 \%$ of the teachers strongly agree and agree respectively that they gave oral introduction by asking questions. However, in item $16,73.4 \%$ of the respondents expressed that they did not order their students to discuss in pair and in group about the writing task in the brainstorming stage. In the same way in item $7,63.4 \%$ of the respondents answered that they did not make their students prepare charts, tables and think about points that should be included and to write them in a paper as they come to their mind in the brainstorming stage. In item 18 also, $63.3 \%$ of the teachers responded that they did not make their students prepare mind map in brainstorming stage.

We can summarize the analysis of the data in table 4 that the teachers gave only oral introduction as a brainstorming. However, the teachers didn't use pair/group discussion and didn't make students prepare mind map, tables charts etc as a brainstorming activity. This implies that teachers gave less attention on brainstorming stage.

Table 5: Teachers 'response on their practice of teaching writing task in planning stage

\begin{tabular}{|c|c|c|c|c|c|c|c|c|c|c|c|c|c|}
\hline \multirow[b]{2}{*}{$\mathrm{Z}^{\prime}$} & \multirow[b]{2}{*}{ Items } & \multicolumn{2}{|l|}{$\mathrm{Sa}$} & \multicolumn{2}{|l|}{ A } & \multicolumn{2}{|l|}{ Un } & \multicolumn{2}{|l|}{$\mathrm{D}$} & \multicolumn{2}{|l|}{ SD } & \multicolumn{2}{|c|}{ Total } \\
\hline & & $\begin{array}{l}\dot{\bar{む}} \\
\stackrel{\Xi}{\Xi} \\
\bar{z}\end{array}$ & 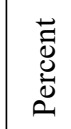 & $\begin{array}{l}\bar{\Xi} \\
\stackrel{\Xi}{\Xi} \\
\text { Zे }\end{array}$ & 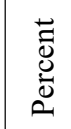 & $\begin{array}{l}\dot{\bar{D}} \\
\stackrel{\Xi}{\Xi} \\
\text { Z }\end{array}$ & 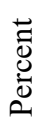 & $\begin{array}{l}\dot{\bar{D}} \\
\text { है } \\
\bar{\Xi}\end{array}$ & $\begin{array}{l}\stackrel{+}{0} \\
\stackrel{0}{0} \\
0\end{array}$ & $\begin{array}{l}\dot{\Phi} \\
\stackrel{\Xi}{\Xi} \\
\text { Z }\end{array}$ & 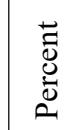 & 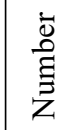 & 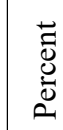 \\
\hline 19 & $\begin{array}{l}\text { Before I order the students to do the } \\
\text { writing task, I ask them to prepare an } \\
\text { outline about their writing task }\end{array}$ & 3 & 10 & 9 & 30 & - & - & 5 & 16.7 & 13 & 43.3 & 30 & 100 \\
\hline 20 & $\begin{array}{l}\text { I order the students to organize their } \\
\text { idea that they come up in the } \\
\text { brainstorming stage. }\end{array}$ & $\beta$ & 10 & 3 & 10 & - & - & 11 & 36.7 & 13 & 43.3 & 30 & 100 \\
\hline
\end{tabular}

Key: SA = Strongly agree, $\mathrm{A}=$ Agree, $\mathrm{Un}=$ Undecided, $\mathrm{D}=$ Disagree, $\mathrm{SD}=$ Strongly disagree

This table is about teachers' practice of teaching writing tasks in the planning stage. As it is shown in item $19,60 \%$ of the teachers responded that they did not make students prepare an outline about their writing task before they do the drafting stage. Similarly, in item $20,80 \%$ of the teachers responded that they did not make students organize their idea that they came up in the brainstorming stage. We can summarize the analysis of table 5 as the teachers did not make students to write an outline and to organize their idea. This implies that teachers give less attention to the planning stage.

Table 6: Teachers 'response on their practice of teaching writing task in drafting stage.

\begin{tabular}{|c|c|c|c|c|c|c|c|c|c|c|c|c|c|}
\hline \multirow[b]{2}{*}{$\mathrm{z}^{\prime}$} & \multirow[b]{2}{*}{ Items } & \multicolumn{2}{|l|}{$\mathrm{Sa}$} & \multicolumn{2}{|l|}{ A } & \multicolumn{2}{|l|}{ Un } & \multicolumn{2}{|l|}{ D } & \multicolumn{2}{|l|}{ SD } & \multicolumn{2}{|c|}{ Total } \\
\hline & & $\begin{array}{l}\dot{\bar{\Xi}} \\
\stackrel{\Xi}{\Xi} \\
\bar{Z}\end{array}$ & 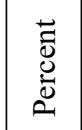 & 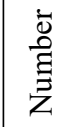 & 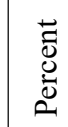 & 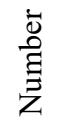 & 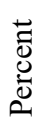 & $\begin{array}{l}\dot{\bar{D}} \\
\text { छ } \\
\text { 乙 }\end{array}$ & 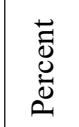 & 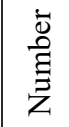 & 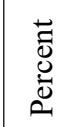 & $\begin{array}{l}\dot{\bar{D}} \\
\text { छ } \\
\text { 乙 }\end{array}$ & 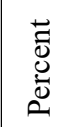 \\
\hline 21 & $\begin{array}{l}\text { I give enough time for my students to } \\
\text { write their first draft in the class. }\end{array}$ & 8 & 26.7 & 6 & 20 & & & 11 & 36.7 & 5 & 16.7 & 30 & 100 \\
\hline 22 & $\begin{array}{l}\text { I support students by moving round in } \\
\text { different groups. }\end{array}$ & 14 & 46.7 & 1 & 3.3 & & & 10 & 33.3 & 5 & 16.7 & 30 & 100 \\
\hline 23 & $\begin{array}{l}\text { I move round the class and monitor } \\
\text { students' progress in the drafting } \\
\text { stage. }\end{array}$ & 12 & 40 & 15 & 50 & - & - & 3 & 10 & & - & 30 & 100 \\
\hline
\end{tabular}

Key: $\mathrm{SA}=$ Strongly agree, $\mathrm{A}=$ Agree, $\mathrm{Un}=$ Undecided, $\mathrm{D}=$ Disagree, $\mathrm{SD}=$ Strongly disagree

As it is shown in table 6 of item $21,46.7 \%$ of the teachers responded that they gave enough time for their students to write their first draft in the class. However, the rest of teachers responded that they did not give enough time. In item $22,50 \%$ of the teachers responded that they moved in different groups and support them, but the other $50 \%$ did not. In item $23,90 \%$ of the teachers answered that they moved round the class and monitor students' progress in the drafting stage. We can summarize table 6 that the time given by the teacher in drafting stage was not enough. What the teachers did in the drafting stage was moving round the class and support students by monitoring their progress. 
Table 7: Teachers 'response on their practice of teaching writing task in revising, editing and rewriting stage.

\begin{tabular}{|c|c|c|c|c|c|c|c|c|c|c|c|c|c|}
\hline \multirow[b]{2}{*}{$\mathbf{z}^{\prime}$} & \multirow[b]{2}{*}{ Items } & \multicolumn{2}{|l|}{$\mathrm{Sa}$} & \multicolumn{2}{|l|}{ A } & \multicolumn{2}{|l|}{ Un } & \multicolumn{2}{|l|}{$\mathrm{D}$} & \multicolumn{2}{|l|}{ SD } & \multicolumn{2}{|c|}{ Total } \\
\hline & & 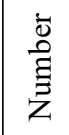 & $\begin{array}{l}\stackrel{\overrightarrow{0}}{0} \\
\stackrel{0}{0} \\
2\end{array}$ & $\begin{array}{l}\overline{\bar{D}} \\
\bar{\Xi} \\
\text { Z }\end{array}$ & 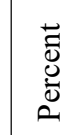 & $\begin{array}{l}\dot{\bar{\Xi}} \\
\text { 节 } \\
\text { Z }\end{array}$ & 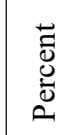 & $\begin{array}{l}\bar{\Xi} \\
\bar{\Xi} \\
\text { Z }\end{array}$ & $\begin{array}{l}\stackrel{+}{\bar{D}} \\
\stackrel{0}{0} \\
0\end{array}$ & 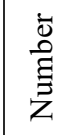 & 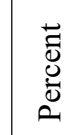 & 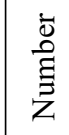 & 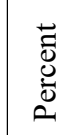 \\
\hline 24 & $\begin{array}{l}\text { After the students finish their first } \\
\text { draft, I give time for them to read and } \\
\text { to make necessary changes on their } \\
\text { writing by themselves. }\end{array}$ & 2 & 6.7 & 5 & 16.7 & 4 & 13.3 & 15 & 50 & 4 & 13.3 & 30 & 100 \\
\hline 25 & $\begin{array}{l}\text { After they finish their first draft, I } \\
\text { give time for peer correction }\end{array}$ & - & - & 7 & 23.3 & - & - & 23 & 76.7 & - & - & 30 & 100 \\
\hline 26 & $\begin{array}{l}\text { After they finish their first draft, I } \\
\text { move round and check students' work } \\
\text { and give comments. }\end{array}$ & - & & 10 & 33.3 & - & & 16 & 53.3 & 4 & 13.3 & 30 & 100 \\
\hline 27 & $\begin{array}{l}\text { I correct and mark students' written } \\
\text { work by nominating some students to } \\
\text { write answers on the black board or to } \\
\text { read aloud and making others } \\
\text { comment on that. }\end{array}$ & 2 & 6.7 & 11 & 36.7 & - & & 17 & 56.7 & . & - & 30 & 100 \\
\hline 28 & $\begin{array}{l}\text { I collect each students exercise book, } \\
\text { assignments and marking out of class }\end{array}$ & & & 9 & 30 & - & & 14 & 46.7 & 7 & 23.3 & 30 & 100 \\
\hline 29 & $\begin{array}{l}\text { I keep records of students' progress of } \\
\text { learning writing tasks and give } \\
\text { additional tasks which can fill the gap } \\
\text { students have. }\end{array}$ & & & & & & & 23 & 76.7 & 7 & 23.3 & 30 & 100 \\
\hline 30 & $\begin{array}{l}\text { I put my signature and give marks on } \\
\text { students' written work. }\end{array}$ & & & 7 & 23.3 & - & - & 13 & 43.3 & 10 & 33.3 & 30 & 100 \\
\hline 31 & $\begin{array}{l}\text { I select one/two students and make } \\
\text { them read their work and I give } \\
\text { general comments for them. }\end{array}$ & 2 & 6.7 & 28 & 93.3 & - & | & - & - & 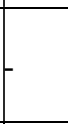 & - & 30 & 100 \\
\hline 32 & $\begin{array}{l}\text { After they finish their first draft, I } \\
\text { make my students rewrite their first } \\
\text { draft based on the comments given by } \\
\text { my teacher and my friends }\end{array}$ & 3 & 10 & 2 & 6.7 & 3 & 10 & 20 & 66.7 & 2 & 6.7 & 30 & 100 \\
\hline
\end{tabular}

Key: $\mathrm{SA}=$ Strongly agree, $\mathrm{A}=$ Agree, $\mathrm{Un}=$ Undecided, $\mathrm{D}=$ Disagree, $\mathrm{SD}=$ Strongly disagree

As it is shown in table 7 of item 24,25 and $26,63.3 \%, 76.7 \%$ and $66.6 \%$ of the teachers respectively responded that they did not give time for self-correction, peer feedback and teacher correction. In item $27,56.7 \%$ of the teachers did no correct and mark students' written work by nominating some students to write answers on the black board or to read aloud and making others comment on that but the rest $43.3 \%$ of the teachers did that. As it is shown in the table, $70 \%$ of the teachers in item 28 responded that they did not collect each student's exercise book, assignments and marking out of class. In the same way, all teachers in item 29 responded that they did not keep records of students' progress of learning writing tasks to give additional tasks which can fill the gap students have. In item 30, 23.3\% of the teachers responded that they put their signature and give marks on students' written work; however, the rest percent of the teachers did not do that. In item $31,100 \%$ of the teachers responded that they gave feedback by selecting one/two students and make them read their work then they gave general comments for them. In relation to rewriting in item $32,73.3 \%$ of the teachers did not make students rewrite their first draft based on the comment. However, only $16.7 \%$ of the teachers made their students to rewrite.

We can summarize the data in the above table as follows. The teachers didn't use peer and self-correction. In addition to this the teachers didn't give written comment by collecting students' exercise book and by moving round the groups. At last the teacher didn't encourage students to rewrite their first draft. What the teacher did was giving oral and general comment. This implies that the teachers gave very little attention to revising editing and rewriting stages of writing process. Besides, they didn't play their role effectively in those stages of writing.

\subsection{Analysis of Data from Teacher s ' interview}

This tool was primarily used to gather data from the five teachers who were observed while teaching writing tasks in five different sections. The total number of interview questions was 7 . The main purpose of the 
interview was to gather data about teachers' perception and their practice of teaching writing tasks. The analysis of results from the five interviewees is presented as follows.

The first interview question was about teachers' opinion about writing tasks of grade 10 English text book. For this question, four of the teachers stated that most of the writing tasks are very useful for students to improve their writing skill. They added that those tasks should be taught in secondary level. For example, teachers one said," If the teachers and students practice those tasks, they are very important for students writing skill improvement". In addition to the importance of writing tasks, most of the teachers (3 in number) stated that implementing the writing tasks need deep preparation from teachers and regularly practice from students. Those teachers said that teaching the writing tasks are a bit challenging for them. For example, teacher 5 said, "Writing tasks are a bit challenging. They need good preparation from teachers and students should practice the writing tasks regularly". From teachers' response we can summarize that teachers had positive perception about writing tasks.

The second interview question was about the teachers' interest to teach writing tasks. For this question, four of the teachers said that they were not interested to teach the writing tasks. They didn't focus on writing tasks and mostly they skipped them. They focus on entrance exam based topics like grammar, reading and vocabulary. For example, teacher three stated that "Practically, I didn't give emphasis for the writing tasks." While one of the teachers (teacher two) said that he gave attention to the writing tasks and he didn't skip them but as he said his students' participation and motivation to learn the writing tasks was very low. The reasons for rest of the teachers for their low interest to teach the writing tasks was the students' low interest to learn writing tasks, the students low participation during writing tasks as well as unsuitability of some the writing tasks to teach in class and shortage of time to cover the text book. For instance teacher 4 stated, "I am not interested to teach writing tasks. This is because some of the writing tasks are not suitable for students. My students are not interested to learn the writing tasks of the text book. They beg me to teach grammar."

From this we can summarize that teachers had no interest to teach writing tasks. The major reasons for teachers' low interest were students' low motivation, low interest, and unsuitability of the tasks. Because of this, the teachers skipped most of the writing tasks.

The third interview question was whether the teachers follow the stages of writing when you teach writing tasks and how they follow such stages. As all interviewees responded they didn't follow the stages of writing. These teachers said that they gave little attention for writing tasks, so they skipped the writing tasks. However, when they sometimes teach writing tasks, they skipped most of the writing tasks stages like brainstorming, planning, revising, editing and rewriting stages. As they said when they teach writing tasks, they ordered the students to take out their exercise book then they write the writing topic on the board/ tell the page number for students, and ordered the students to write ob the given topic. For instance, as teacher 3 stated, "I don't follow the stages of writing. In the brainstorming and planning stages, I give only oral introduction. In the revising, editing and rewriting stages of writing, I give general comment. What I give emphasis is drafting stage." In the post writing stage the teachers stated that they would select one /two students and ordered them read their writing and gave general comment. For example, teacher 1 state "In brainstorming and planning stage, I give oral introduction and in the post tasks phase I select one/two students' written work and give general comment." Their reasons they didn't follow the stage of writing were shortage of time to teach the writing tasks following these stages and student's passive participation in these stages of writing. For example, teacher one said "... except drafting stage, the students were passive in the rest of the writing stages and the period is not enough to teach the students following the stages of writing." From this we can understand that the teachers didn't follow the stages while they teach the writing tasks. This also indicates that they give little attention on the pre and post tasks activities.

The forth interview question was teachers' opinion about their role in writing period. For this question, the teachers mention their roles. As they said the roles of the teacher during writing period are bringing writing tasks in class, facilitating the teaching learning process, monitoring and supporting students in every stage of writing, managing time, and giving feedback. For instance, teacher 5 reported, "The teacher should be prepared well and facilitate the teaching learning process. The teacher should arrange students in different groups and monitor students' progress and should give marks for the students' written work." From the responses of teachers in question four, it is possible to say that the teacher have positive (good) perception about the role of the teacher in writing period.

The fifth interview question was teachers' opinion about feedback. All the teachers stated that feedback is important for students and it should be given for them. The teachers also added that error correction helps students to evaluate whether their writing ability is good or not. For example, when we see teacher 2, he said," Feedback is important for students. The students can learn from their friend. If students do not get comments, they may consider what they write is correct and the error becomes fossilized." From this item we can summarize that the teachers have positive perception about the importance of feedback.

The sixth interview question was about their way of giving feedback. All of the respondents responded that 
they gave less emphasis for feedback because of shortage of time. When they elaborate it, they said that most of the teachers ordered the students to finish the writing tasks in their home and because of that they give feedback rarely for their students. How most of the teachers give feedback was by selecting one or two students to read their written work and then they give general comment for the whole students. For example, teacher one said, "Usually I don't give comment for the students since most of the time I order to finish their writing in their home. I rarely supervise some students' exercise book and I give general comment. I rarely order the students to comment their friends' work." From this we can conclude that the teachers didn't give sufficient and appropriate feedback for the students. This implies that the teachers gave little attention on students' feedback. This is because only oral and general comment will not enable the learners to identify their errors and to improve their writing skill. The teachers should move in different groups and should help students in every stage of writing. "We need to look not at responses written on final drafts but rather at responses written on immediate drafts, and at how those drafts were reshaped as a result of the teachers' comments" (Leki, 1990, p. 63).

The seventh category is the extent to which the students are exposed to different writing tasks. For this question the teachers responded they skipped most of the writing tasks because of students' interest. As they said they depend only text based writing tasks which are suitable to conduct it in the classroom, not tasks adopted and adapted by the teachers. They also responded that they didn't make students practice the writing tasks by dividing it in different stages because of shortage of time to pass through those stages of writing. Moreover, most of the time they didn't give writing tasks as an assignment and as project work. For instance teachers 1 stated, "I skipped most of the writing tasks. I sometimes order them to write the writing tasks. However, I don't have time to help students in every stage of writing and to give additional writing tasks in class." From this we can understand that the teachers didn't make students practice different writing tasks. However, the teachers should make students practice the writing tasks regularly and should make students actively involved in the tasks. The teachers should also prepare writing tasks by him/her in addition to text based writing tasks and should expose the students for these tasks. Unless the students practice the writing tasks they will not improve their writing skill.

In general, from the responses of teachers in item 7, we can imply that the teachers didn't implement the writing tasks as they perceive that is writing tasks need regular practice and the writing tasks should be practiced using process approach.

\section{Discussion}

The main purpose of this study was to explore teachers' perception and their practice of teaching writing tasks. Below are discussions and triangulation of the findings of the data based on the research objectives.

The first objective of this research was to explore the perception of teachers on writing tasks. Data about this objective were collected using teachers' questionnaire (found in table 1-3) and teachers' interview (question number 1, 4 and 5). As it is shown in table 1, more than $90 \%$ of the teachers responded that the writing tasks require critical thinking and regular practice and they are as important as grammar and vocabulary. This result is also reflected in interview question number one. As the teachers responded in interview question number one, writing tasks are useful, but they need critical thinking and regular practice. Therefore, it is possible to say that the teachers have positive perception about the nature of writing tasks.

When we see teacher's perception about teaching writing tasks, as it is shown in table two of item 4 and 5 , more than $90 \%$ of the teachers perceive that writing tasks should be taught at high school level and should not be left to higher institution. In addition to this, more than $80 \%$ of the teachers responded in table two, teaching writing tasks is more difficult than teaching other tasks and it requires more effort from teachers. This result is also reflected in teachers' interview question one. As we can see it in interview part, the teachers responded that teaching writing tasks need efforts from teachers and students but they said that teachers should teach these writing tasks. This result confirms with Langan's (2005) and Heaton's (1988: 135) study. The difficulty and complexity in EFL/ESL writing task is from the fact that writing includes discovering a thesis, developing support for the thesis, organizing, revising, and finally editing the thesis to ensure an effective, error- free piece of writing (Langan, 2005). Heaton (1988: 135) also adds that writing tasks are complex and sometimes difficult to teach, requiring mastery not only of grammatical and rhetorical devices but also of conceptual and judgmental elements. This implies that the teachers had perception about teaching writing tasks.

In relation to teaching approach, more than $80 \%$ of the teachers in item 8,9 and 10 responded that fluency is better than accuracy. Process approach of teaching is better and it is not time consuming. This idea is supported by McDonough and Shaw (1993:189). They state that "intervention is usefulness at all stages of writing, not just at the end of the process of writing, not just to be observed with the final product." (Hedge,1988; McDonough and Shaw, 1993; White and Arndt, 1991) explain the process approach to writing as one takes appropriate writers through the various stages when they are producing a piece of written work. This implies that the teachers prefer process approach of teaching writing tasks over the product approach of teaching.

The other point the researcher want to discuss here is teachers' perception on feedback. As it is shown in 
table 3 of items 11,12 and 13, more than $86.7 \%$ of the teachers perceive that feedback given by peers and by their teacher is helpful for students' writing skill improvement. In item 14, all of the teachers responded that rewriting is important for students to write better. This result is the same as the result of teachers' interview. In interview question number 5, the teachers' believed that feedback is important for students and it should be given for their students. Based on the results obtained from teachers' questionnaire and teachers' interview, we can say that the teachers have positive perception about feedback. This result confirms with Chaudron's (1988) report. He stated that feedback is a major means through which teachers inform learner's correctness of their target language production.

The second area of discussion is about implementation of writing tasks. Data about teachers' practice of teaching writing tasks were collected from teachers' questionnaire of table 4- 7, teachers' interview question number 2,3 and 6 , and classroom actual observation.

In the brainstorming stage, the teacher made students to brainstorm by giving oral introduction. As it is shown in table 4 of teachers' questionnaire, more $63.3 \%$ of the teachers responded that they gave oral introduction. However, $75 \%$ and $63 \%$ of the teachers didn't make students to discuss in group and to prepare mind map, charts and tables in the brainstorming stage. In addition to teachers' questionnaire, classroom actual observation data also reflected this result. As the researcher observed what the teachers did in this stage was giving oral introduction. Teachers' interview question number 3 also reflected this point that is the teachers didn't give time for students to practice the brainstorming stage of writing. Therefore, we can say that only oral introduction is given in the brainstorming stage. To the contrary of these Pincas (1989) states that the various activities students /writers need to do during brainstorming are talking about their likes and dislikes and things, people, places and hobbies depending on the particular topic they are discussing. He also added that during this stage, the teacher may order the students to sit and discuss in groups/ pairs and come up with ideas that can be included in their writing. This implies that the teachers did not implement the brainstorming stage properly. That means the teachers gave little attention to the brainstorming stage. This will also affect students' progress in the next stage of writing. This is because, the activities in this phase are expected to give learners relevant exposure to the topic language and above all, create interest in doing the task (Willis, 1996).

In the planning stage more than $60 \%$ of the teachers in table 5 responded that they didn't give time for their students to prepare an outline and to put framework of their writing. In addition to this, teachers' interview question number 3 and the observation data show that the teachers gave only oral introduction but didn't make the students to plan about their writing. To the opposite of this White (1989) identifies different ways of planning writing for instance, creating a cluster, or web of ideas, making an outline, identifying pros and cons etc. He added that this stage is an important one for it allows students set some kind of framework for their writing before they begin writing the first draft. From the result it can be said that the teachers were rarely applying the planning stage.

In the drafting stage $53.3 \%$ of the teachers in table 6 responded that they did not give enough time for students to write their first draft in the classroom. In addition to this, $90 \%$ and $50 \%$ of the teachers in table 6 responded that they move round the class and monitors students' progress and they support students by moving in different groups respectively.

However, their response contradicts with the actual classroom observation. As the researcher observed, the teachers sat somewhere but didn't move round and didn't support the students in each stage of writing. From this we can say that the teachers didn't give valuable data here because they may exaggerate themselves. Therefore, it is better to take the finding of the actual observation that is the teachers did not move round and did not help the students in the drafting stage. This result contradicts with Martin's study. Martin (2011) states that the teacher should act as a facilitator of the learning process in writing class. As a result of this, it is possible to say that the teachers in those schools didn't play their role in the drafting stage of writing.

The last point the researcher want to discuss in the teaching of writing tasks is how the teacher implement the revising, editing and rewriting stage. In relation to these stages the researcher collected data from teachers' questionnaire, data from observation and teachers' interview. After the students finish doing their first draft, the teacher should give time for the students to vise their draft and to look the flow of idea, arrangement of idea and the layout of their work. To the contrary of this, the teachers didn't make students to do the revising stage activities. In the editing stage the students should edit the grammar, spelling, punctuation and other sentence errors by themselves, in pair or in group. However, as $63.3 \%$ and $76.7 \%$ of the teachers in table 7 , responded that they didn't give time for self and peer correct respectively. The classroom observation and teachers interview result showed the same result that is the teachers didn't use self and peer correction. To the contrary of this finding Pincas (1989) states that if something is written in the classroom by the students, it is intended to be read by the teacher and or by other students in order to get feedback. In addition to peer and self-correction, $66.6 \%$, $70 \%$ and $100 \%$ of the teachers responded they didn't move round to comment students' work, didn't collect students' exercise book and didn't keep records of students' progress respectively in this stage of writing process. The observation and interview data also show that the teachers didn't give written feedback for students by 
moving round and by recording students' errors. To the reverse of the finding, Chaudron (1988) states feedback is a major means through which teachers inform learner's correctness of their target language production. What the teachers did in post task phase (revising, editing and rewriting) was give general comment for the students. As is shown in table 7, 100\% of the teachers stated that they give general comment for the students. This result also reflected in interview that is 4 of the teachers stated that they give general comment. The observation data also show this result. From this we can say that the teachers gave only general comment.

From the above discussion it is possible to say that the teachers gave little attention to feedback. The teachers did not give specific comments and didn't use other ways of giving feedback like peer feedback, selfcorrection, and model corrections, collecting students exercise book, giving assignment and mark it etc.

In rewriting stage, all the teachers responded that they didn't make the students rewrite their first draft based on the comments given by their friends and their teacher. The interview and observation data revealed the same result. This shows that the teachers did not make students rewrite their first draft. This implies that rewriting stage is totally ignored by the teachers..

Generally, in the second area of discussion we can summarize that the teachers gave very little attention to the writing process. Most of the teachers' didn't teach writing tasks by dividing the task in phases. From the discussion it is also found that the teachers didn't play their role which is listed by Hyland (2003:12) in chapter two effectively in each stage of writing. In addition to this, they didn't make students practically apply the writing tasks following the stages of writing. Especially they didn't give emphasis for brainstorming, planning, revising, editing and rewriting sates of writing.

The third focus area of the discussion is whether the teachers teach writing tasks as they perceive. In the teachers perception part (table 1-3) we discussed that the teachers perceive that the writing tasks are important and they need critical thinking and regular practice. However, in the data of observation and teachers' interview, the teachers didn't give emphasis for writing tasks and mostly they skipped the writing tasks. Teachers interview question 6 , indicate that the teachers didn't make students to practice regularly by giving additional writing tasks.

The teachers also perceived that teaching writing tasks needs more effort from teachers and students should learn writing tasks. However, in the practice of the writing tasks, as it is above teachers didn't play their role properly. They didn't help students in every stage of writing. Most of the teachers skip the writing tasks.

The teachers also perceive that feedback is important for students and it should be given for them ( see table 3). However, as it is shown in table 7, the teachers didn't give adequate feedback for the students.

Lastly, the teachers perceive that process approach is useful to implement the writing tasks than product approach of teaching. However, as we can see from teachers' questionnaire, the teachers didn't follow stages of process of teaching. Therefore, the teachers use product approach of teaching.

In general in the third discussion area, we can conclude that the teachers are unable to apply their theoretical knowledge for the actual practice of teaching writing tasks. This means they didn't teach writing tasks as they perceive.

\section{CONCLUSIONS AND RECOMMENDATIONS}

\subsection{Conclusion}

Based on the findings of the study the following conclusions were drawn:

$>$ The teachers had positive perception about nature of writing tasks, teaching of writing tasks and feedback.

$>$ The teaching and learning process of writing tasks in those schools was not implemented as it was intended in the curriculum. The teachers didn't teach writing tasks following the stages of writing. Besides the teachers didn't make students practice the writing tasks following the stages of writing. This will have a negative impact on the students writing skill.

$>$ During the writing task implementation, the teachers didn't play their role effectively in each stage of writing. Teachers didn't give fruitful feedback to the students on the students' writing works. The way the teachers gave feedback (general comment) will not help the students to improve their writing.

$>$ The teachers' perception of the writing tasks didn't match with their practice. That means the teachers didn't teach writing tasks as they perceive.

$>$ In general, the findings of the study are the teachers had positive perception about writing tasks. However, they didn't teach the writing tasks following the stages of writing and didn't help students in each stage of writing process. Therefore, it is concluded that the teachers didn't practice the writing tasks as they perceive it.

\subsection{Recommendation}

Based on the findings and the conclusions made, the following recommendations were drawn:

$>$ Teachers and students should give emphasis on the writing tasks and they should play their roles 
effectively in the implementation of writing task.

$>$ Teachers should teach the writing tasks in stages of writing and should make students follow these stages of writing. Moreover, they should support the students in each stages of writing.

$>$ Assessing students' writings should be included in school examinations in order to make students give attention on writing tasks.

$>$ Finally, the investigator would like to recommend that further research needs to be conducted on the topic under the suitability of grade 10 English text book writing tasks for teachers and students and come up with the possible change that would be made in writing tasks of grade 10 English text book.

\section{References}

Abiy Yigzaw. 2013. High School Students' Writing Skill and their English Language Proficiency as predictors of Their English Language Writing performance -Ethiop.j.educ.\& sc.vol.9 no.1.

Alamirew G/Mariam. 2005. A Study on the Perception of Writing, Writing Instruction and Students' writing Performance (Unpublished PhD Dissertation). Addis Ababa: Addis Ababa University.

Arndt, V. 1988. Approaches to Process Writing (Teaching English). Oxford: Oxford University Press.

Ary, D., Jacobs, L.C., Sorensen, C. and Razavieh, A. 2010. Introduction to Research in Education. Wadsworth Cengage learning, USA.

Byrne, D. 1991. Teaching Writing Skills. UK: Longman Group UK Limited.

Chaudron ,C. 1988. Second language classrooms: Research in teaching -learning. Cambridge: Cambridge university press.

Creswell, J. W. 2014. Qualitative, Quantitative and Mixed Method Approaches. SAGE Publications Ltd. California, USA.

Dawit Amogne. 2013. Enhancing Students' Writing skills Through the Genere Approach. International Journal of English and Literature .4 (5), pp242-248.

Desalegn Simachew. 2011. A Study of the Practice of Teaching Writing Skills: the Case of Bahir Dar University. (Unpublished MA Thesis).Addis Ababa: Addis Ababa University.

Geremew Lemu. 1999. A Study of the Requirements in Writing for an Academic Purpose at Addis Ababa University. (Unpublished PhD Dissertation).Addis Ababa: Addis Ababa University.

Hailmariam W/G. 2012. Problems Students Face in Writing: Grade 10 Students of Higher 12 Secondary Schools in Focus. (Unpublished MA Thesis). Addis Ababa: Addis Ababa University.

Heaton, J.B. 1988. Writing English Language Test. New York: Longman Group UK Limited

Hedge, T. 2005. Writing. Oxford: Oxford University Press.

Hyland, K. 2006. English for Academic Purposes. New York: Taylor\& Francis e-Library.

Kumar, S.Y. 2006. Fundamental of Research Methodology \& Statistics. New Delhi: New Age International (P) Ltd.

Langan, J. 2005. College writing with readings. New York.

Leki, I. 1991. "Teaching Second Language Writing: Where We Seem to Be," English Teaching Forum, 32 (2): 43-57.

Littlewood, W. 1981. Communicative Language Teaching. Cambridge: Cambridge University Press.

Martin, M. 2011. Second language learning in the early school years. Oxford applied linguistics. Oxford university press.

Nunan, D. 1988. Syllabus Design. Oxford: Oxford University Press

Nunan, D. 1989. Designing Tasks for Communicative Classroom. Cambridge: Cambridge University Press

Pincas, A. 1989. Teaching English Writing. London: Macmillan Publishers Ltd

Richards, J. and Rodgers, T. 1986. Approaches \& Methods in Language Teaching: Description \& Analysis. Cambridge: Cambridge University Press.

Richards, J.C. and Rodgers, T.S. 2001. Approaches and Methods in Language Teaching. Cambridge University Press, New York, USA.

Selinger, H. W., and E. Shohamy. 1989. Second Language Research Methods. Oxford: Oxford University Press.

Squire, J.R. 1979. "Instructional Focus on the Teaching of Writing." Aviva Freedman, Ian ,Pringle and Janic Yalden ( editors). Learning to write: First language/Second Language. Lendon and New York: Longman Inc.

White, R. 1989. Teaching Written English. London: Heinemann International

White, Ron \& Arndt, Valery. 1991. Process Writing. England: Duke of Edinburgh English Language Book Competition Teacher's Book.

Willis, J. 1996. A Framework for Task-based Learning. London: Longman 